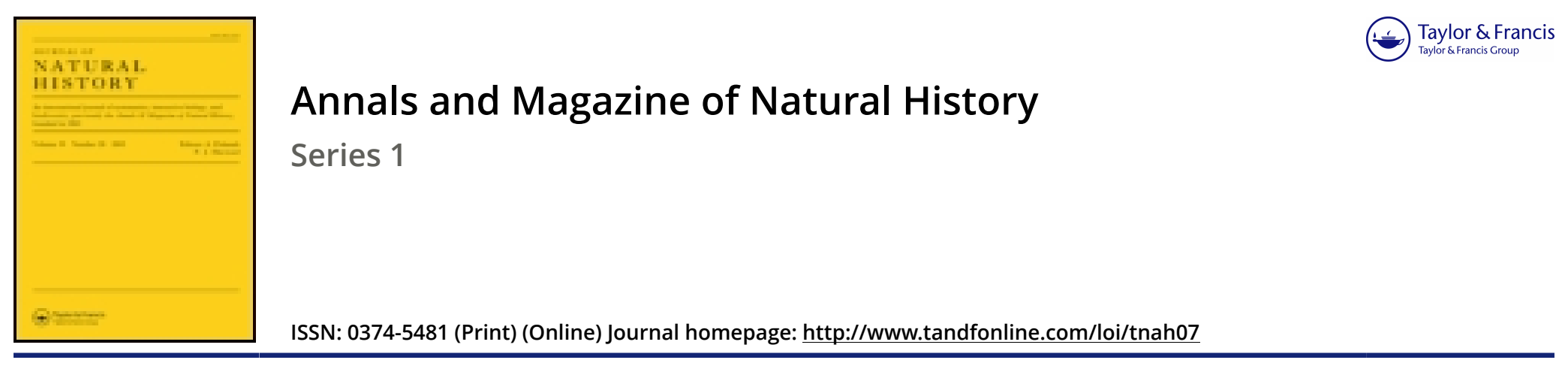

\title{
XV.-Description of a new genus of night lizards from Belize
}

\section{J.E. Gray Esq. F.R.S.}

To cite this article: J.E. Gray Esq. F.R.S. (1845) XV.-Description of a new genus of night lizards from Belize, Annals and Magazine of Natural History, 16:104, 162-163, DOI: 10.1080/037454809495922

To link to this article: http://dx.doi.org/10.1080/037454809495922

册 Published online: 16 Dec 2009.

Submit your article to this journal $\sqsubset \pi$

Q View related articles $\asymp$

4 Citing articles: 1 View citing articles 진 
$x$, oval body with which vas deferens communicates; $y$, sac of unknown function; $z$, dichotomously divided tube which opens into the sac $y$; $\beta$, tube connecting the sac $y$ with the oval body $x$; $\gamma$, the testis ?; $\partial$, pyriform sae connected with $\gamma ; \zeta \zeta \zeta$. the ovary?; $\theta \theta$, capsular bodies connected with ovary.

\section{Prate Vil.}

Fig. 1. System of œsophageal ganglia : $a$ a, great supra-œsophageal ganglia ; $b b$, second pair ; $c c$, third pair; $d$, azygous ganglion ; $e$, commissures connecting supra-cesophageal ganglia with azygous ganglion; $f$, commissure which runs beneath the osophagus and unites the two ganglia of the second pair; $g g$, organs of hearing.

Fig. 2. Organ of vision: $a$, pigmental body ; $b$, optic nerve; $c$, crystalline lens ; $d$, transparent capsule inclosing pigmental body and lens.

Fig. 3. Subcutaneous mucous glands.

Fig. 4. Terminal culs-de-sac of the hepatic system.

Fig. 5. The tongue: $a$, lingual sac; $b$, unarmed prolongation, in which the tongue terminates at the right side.

Fig. 6. Portion of posterior salivary glands.

Fig. 7. One of the oval bodies contained in the ovarian capsules.

Fig. 8. Portion of the ovary with its capsule : $a a b$, sacciform appendages; $b$, capsule ; $c$, oval bodies inclosed by the capsule.

Fig. 9. Group of ova as deposited upon the leaves of Zostera marina, \&c.

Fig. 10, 11, 12. Embryo: $a$ a, locomotive discs ; $b$, foot; $c$, operculum ; $d$, organs of vision; $e$, esophagus ; $f$, stomach; $g$, granular mass, beneath which the posterior part of the alimentary canal is concealed; $h$, rudiments of cesophageal ganglia ; $i$, filaments which pass backwards from the base of the discs.

XV.-Description of a new genus of Night Lizards from Belize. By J. E. GraY, Esq., F.R.S. \&c.

\section{To the Editors of the Annals of Natural History.}

GRNTLEMEN,-This interesting new form of Gecones, or Night Lizards, was sent from Belize by Mr. Dyson under the name of "Gallwaspe," a name which appears to be generically applied to most Lizards by the English in Tropical America. It is at once distinguished from all the genera of the family before known by the short, blunt, compressed, equal-diametered toes, but more particularly by the very small size of the claws, which are completely hidden between two large, half oblong scales, which have a narrow one between the base of the upper edge.

\section{Genus Coleonyx. Fam. Gecotida.}

Toes rather compressed, equally thick their whole length, blunt at the end; edges simple, rounded; upper surface covered with a single, and the sides with three series of six-sided scales, the under surface with a single series of rather narrow, slightly convex, transverse scales; the end of each toe furnished with large, oblong, convex scales on each side, forming a complete sheath to the small claws, and with 
an elongate tapering scale covering the suture between these two scales above. Preanal pores distinct, in an angular series; scale granular, with series of larger, round, convex granules. Tail cylindrical, with rings of larger subangular tubercles, swollen near the vent beneath, and with large tubercles on each side.

Coleonyx elegans. Gray; head and nape with concentric black streaks; back and tail with irregular black cross-bands, beneath gray; back with numerous series of roundish tubercles, smaller and more distant on the hend and nape, and more crowded on the limbs.

Inhab. Belize. Collection of the British Museum.

\section{XVI.-The Arctic Expedition under the command of Sir JoHN FrankLIN.}

$W_{\mathrm{E}}$ have been favoured with the sight of letters from Mr. H. Goodsir, who is attached to this expedition, and hasten to communicate to our readers an outline of the results already obtained. The zeal and scientific knowledge of our friend Mr. Goodsir have raised high anticipations of the value to natural science of this voyage, and these have, if possible, attained a still greater elevation by what has been already done. It is most satisfactory to learn that the officers of the expedition, and also a considerable number of the men, are most active in rendering every assistance to him in his researches. They have indeed kept him at work almost night and day (if there can be said to be any night in these latitudes), examining, drawing, and describing new or highly interesting animals.

We will now proceed to give a short account of the voyage, as learned from Mr. Goodsir's letters, which are dated from "Disco in Baffin's Bay, July 7, 1845."

The earlier part of the voyage was rather tedious, owing to adverse and stormy winds, so that the ships were driven far to the north-east, near enough on June 11th to have seen the mountains of Iceland, had the state of the atmosphere allowed. On the 22nd they were off Cape Farewell, the southern point of Greenland. Up to this date there were only two days upon which he could make any observations, but the results of these are extremely interesting. On the 10th of June, in lat. $61^{\circ} 47^{\prime}$, long. $14^{\circ} 14^{\prime}$, numerous specimens of a species of Briareus were obtained, furnishing an important addition to our knowledge of these animals. The presence of "cilia fringing the bifurcated portions of the lateral extremities of its body," decides the position of the genus in nature, and proves that Quoy and Gaimard's idea of its being molluscous is not correct. Its intestinal canal consists of a straight tube with but one oval opening. The re- 